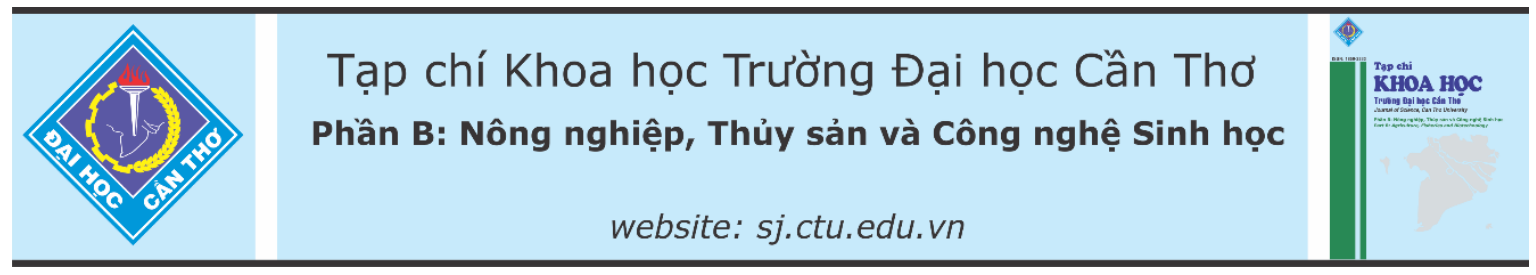

DOI:10.22144/ctu.jvn.2021.119

\title{
ĐA DẠNG DI TRUYỀN CÁC GIỐNG SẦU RIÊNG (Durio zibethinus) DỰA TRÊN TRÌNH TỬ DNA MÃ VẠCH VÀ CHİ TH!̣ PHÂN TỬ ISSR
}

Đỗ Tấn Khang ${ }^{1 *}$, Phan Thanh Huynh ${ }^{2}$, Trần Gia Huy ${ }^{3}$, Nguyễn Phạm Anh Thi ${ }^{1}$, Trần Thanh Mến ${ }^{4}$ và Nguyễn Văn $\hat{A} y^{5}$

${ }^{1}$ Viện Nghiên cứu và Phát triển Công nghệ sinh học, Truờng Đại học Cần Tho

${ }^{2}$ Sinh viên ngành Công nghệ sinh học Khóa 43, Truòng Đại học Cần Tho'

${ }^{3}$ Học viên cao học ngành Công nghệ sinh học Khóa 26, Truờng Đại học Cần Tho

${ }^{4}$ Khoa Khoa hoc tư nhiên, Trường Đại hoc Cần Tho

${ }^{5}$ Khoa Nông nghiẹp, Truoòng Đại hoc Cần Tho

*Ngưòi chịu trách nhiệm về bài viết: Đỗ Tấn Khang (email: dtkhang@ctu.edu.vn)

\section{Thông tin chung:}

Ngày nhận bài: 25/02/2021

Ngày nhận bài sủa: 11/05/2021

Ngày duyệt đăng: 20/08/2021

\section{Title:}

Genetic diversity of durian (Durio zibethinus) varieties based on DNA barcode sequences and inter simple sequence repeat markers

\section{Tù khóa:}

DNA mã vạch, ISSR, ITS,

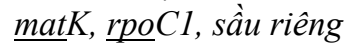

\section{Keywords:}

DNA barcode, durian, ISSR, ITS, $\underline{\operatorname{mat} K}$, rpoCl

\begin{abstract}
Durian (Durio zibethinus) is one of the special fruits in Vietnam favored with high trade in the world. Currently, there are many varieties of durians grown in the Mekong Delta, and it is challenged to distinguish them through morphology. This study was aimed to examine genetic diversity based on DNA barcode and the ISSR molecular marker. The DNA sequences of three barcode DNA candidates,

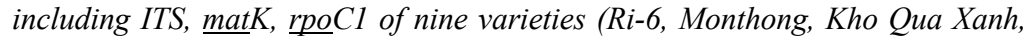
Chin Hoa, Sua Hat Lep, Chuong Bo, Bi, Musang King, and Sau Huu) collected from Can Tho, Tien Giang, Ben Tre and Vinh Long were sequenced and analyzed. Six SNPs were identified from the ITS sequence between individuals Ri-6-Ben Tre, Monthong-Tien Giang, Chuong Bo-Tien Giang, Sua Hat Lep-Can Tho, and Sau Huu-Tien Giang. For the matK gene, nine SNPs were found to distinguish Ri-6 individuals (Can Tho and Southern Fruit Research Institute), Chin Hoa-Ben Tre, Sua Hat Lep-Ben Tre and Sau Huu-Tien Giang. The rpoCl gene was highly conservative between varieties in this study. The ISSR molecular markers classified such durian varieties into five groups and showed clear differences between the exotic varieties of Musang King-Vinh Long and Monthong-Tien Giang.
\end{abstract}

\section{TÓM TẮT}

Sầu riêng (Durio zibethinus) là một trong nhũng giống cây ăn quả đặc sản của Việt Nam được thị trương ua chuộng. Hiện nay có nhiều giống sầu riêng được trồng tại Đồng bằng sông Cưu Long (ĐBSCL) và khó phân biệt được qua hình thái. Đề tài được thực hiện nhằm bước đầu khảo sát về mặt di truyền dụa trên DNA mã vạch và chì thị phân tử ISSR. Trình tụ DNA của ba locus DNA mã vạch gồm ITS, matK, rpoCl của chín giống (Ri-6, Monthong, Khổ Qua Xanh, Chín Hóa, Sũa Hạt Lép, Chuồng Bò, Bí, Musang King và Sáu Hũu) đuợc thu tù Cần Tho, Tiền Giang, Bến Tre và Vĩnh Long đã được giải trình tụ và phân tích. Nghiên cưu đã xác định 6 SNPs của vùng ITS giũa các cá thể Ri-6-Bến Tre, MonthongTiền Giang, Chuồng Bò-Tiền Giang, Sữa Hạt Lép-Cần Tho và Sáu Hũu-Tiền Giang. Đối với vùng trình tụ matK tìm được 9 SNPs phân biệt được các cá thể Ri6 (Cần Tho và Viện Cây ăn quả miền Nam), Chín Hóa-Bến Tre, Sũa Hạt Lép-Bến Tre và Sáu Hũu-Tiền Giang. Vùng trình tụ rpoCl có độ bảo tồn cao giũa các giống trong nghiên cứu. Cây phân loại dựa trên các dấu phân tủ ISSR đã tách các giống sầu riêng thành 5 nhóm và cho thấy sự khác biệt rõ của giống sầu riêng nhập ngoại Musang King-Vĩnh Long và cá thể sầu riêng Monthong-Tiền Giang. 


\section{GIỚI THIỆU}

Sầu riêng (Durio zibethinus) là một trong những loại cây ăn quả đặc sản và có giá trị kinh tế cao ở Việt Nam. Xuất xứ từ vùng đất nhiệt đới ẩm ở Đông Nam Á, sầu riêng được trồng nhiều ở Indonesia, Malaysia, Philippines, Myanmar, Thái Lan, Lào, Campuchia, ... ngoài ra còn được trồng ở một số nước nhiệt đới khác ở Trung Nam Mỹ, một số nước châu Phi và châu Đại Dương như Úc. Sầu riêng được coi là một loại cây ăn trái quan trọng do có thời gian thu hoạch kéo dài và cho giá trị kinh tế cao (Nguyễn Danh Vàn, 2008). Tại Việt Nam, sầu riêng được trồng nhiều ở các tỉnh như: Đắc Lắc, Đồng Nai, Bình Dương, Bình Phước, Bến Tre, Tiền Giang, Vĩnh Long, Cần Thơ,... với diện tích khoảng 13.000 ha, sản lượng 150.000 tấn (Bộ Công Thương, 2019). Bộ Nông nghiệp và Phát triển Nông thôn (2013) đã định hướng phát triển sầu riêng là một trong 12 chủng loại cây ăn quả chủ lực trồng tập trung ở Nam Bộ với diện tích là 15.000 ha và được bố trí diện tích trồng rải vụ 5.250 ha đến năm 2020 . Sầu riêng đông lạnh được thị trường nhiều nước ưa chuộng là mặt hàng xuất khẩu có giá trị rất cao. Trong tập đoàn cây ăn quả nhiệt đới của nước ta, sầu riêng có tiềm năng phát triển rất lớn góp phần tăng giá trị xuất khẩu.

Tại Đồng bằng sông Cửu Long (ĐBSCL) hiện đang được trồng rất nhiều giống sầu riêng khác nhau như: sầu riêng Khổ Qua Xanh, sầu riêng Ri 6, sầu riêng Chuồng Bò, sầu riêng Chín Hoá, sầu riêng Monthong (nhập ngoại),... Tuy nhiên cho đến nay, có rất ít thông tin về mối quan hệ di truyền giữa các giống sầu riêng bao gồm các giống sầu riêng phổ biến có nguồn gốc từ các quốc gia Châu Á (Husin et al., 2018). Ở giai đoạn cây con, việc phân loại các giống cây trồng dựa vào hình thái có độ tin cậy thấp cho thiếu các tính trạng đặc trưng. Do đó, các chỉ thị phân tử đóng vai trò quan trọng trong công tác nhận diện giống. DNA mã vạch là một phương pháp định danh và giám định loài dựa trên các trình tự $\mathrm{DNA}$ ngắn ở những vùng chuẩn hóa của DNA hệ gene (Hebert et al., 2003). Hướng nghiên cứu này đang được nhiều quốc gia, nhiều nhà khoa học trên thế giới quan tâm phát triển, đặc biệt trong những năm gần đây và sẽ là một xu thế nghiên cứu trong thời gian tới. DNA mã vạch được xem là một công cụ mới, hỗ trợ có hiệu quả trong nghiên cứu về phân loại, phát hiện loài mới, giám định loài và các mẫu có nguồn gốc từ sinh vật sống hoặc đã chết thậm chí đã qua chế biến.
Nghiên cứu đa dạng di truyền và bảo vệ nguồn gene của các giống sầu riêng tại ĐBSCL có ý nghĩa rất quan trọng trong việc bảo tồn tính đa dạng sinh học sử dụng có hiệu quả các nguồn gene và phục vụ cho công tác chọn tạo giống. Ngoài giá trị khoa học xác định giống loài, một hệ thống quản lý giống dựa vào các kỹ thuật sinh học phân tử sẽ giúp quản lý được tài nguyên di truyền để khai thác hiệu quả và có đủ cơ sở khoa học để chứng minh được quyền sở hữu quốc gia đối với nguồn tài nguyên sinh học, khi Việt Nam gia nhập AFTA và tổ chức thương mại quốc tế (Trần Nhân Dũng và Đỗ Tấn Khang, 2012). Chính vì thế việc thực hiện đề tài "Nhận diện giống sầu riêng Ri 6 bằng DNA mã vạch" nhằm phân loại và xác định giống sầu riêng Ri 6 và các giống sầu riêng được trồng phổ biến dựa trên vật liệu di truyền là rất cần thiết. Nghiên cứu này được tiến hành với mục tiêu phân tích được đặc điểm trình tự nucleotide, so sánh khả năng phân định và nhận diện giống sầu riêng Ri 6 với các giống sầu riêng khác dựa trên trình tự vùng trình tự ITS, $m a t \mathrm{~K}, r p o \mathrm{C} 1$ và chỉ thị phân tử ISSR.

\section{VẠT LIỆU VÀ PHƯƠNG PHÁP}

\subsection{Thu mẫu}

Các giống sầu riêng như: Ri 6, Monthong, Khổ qua xanh, Chuồng bò, Sữa hạt lép, Chín Hóa, Sáu Hữu, Musang King và sầu riêng Bí được thu tại các trại giống và các nhà vườn có diện tích trồng lớn ở các tỉnh Tiền Giang, Bến Tre, Vĩnh Long và Cần Thơ, mẫu được bảo quản trong túi nilon và ghi đầy đủ thông tin mẫu.

\subsection{Ly trích DNA tổng số}

Các mẫu lá được rửa bằng nước sạch sau đó khử trùng bề mặt bằng ethanol $70 \%$. Mẫu được cắt nhỏ, ủ với nitrogen lỏng trong vòng 5 phút và nghiền thành bột mịn. Quy trình ly trích được hiệu chỉnh theo mô tả của Roger and Bendich (1988). DNA được kiểm tra bằng kỹ thuật điện di trên gel agarose $1 \%$.

\subsection{Khuếch đại và giải trình tự DNA mã vạch}

Mỗi phản ứng PCR được thực hiện với thể tích $50 \mu \mathrm{L}$ gồm các thành phần: $25 \mu \mathrm{L} \mathrm{BiH} \mathrm{BiH}_{2} \mathrm{O} ; 20 \mu \mathrm{L}$ Master Mix (Buffer, $\mathrm{MgCl}_{2}$, dNTPs, Taq polymerase); $1 \mu \mathrm{L}$ mồi xuôi và ngược $(20 \mu \mathrm{M}) ; 3$ $\mu \mathrm{L}$ DNA khuôn. Thông tin mồi và chu kỳ nhiệt được mô tả ở Bảng 1 . Sản phẩm PCR được điện di trên gel agarose $2 \%$ ở hiệu điện thế $50 \mathrm{~V}$ trong 40 phút và kiểm tra bằng hệ thống Gel Doc XR (Bio-rad, Mỹ). Các sản phẩm PCR đạt chất lượng được giải trình tự tại Công ty Nextgen. 
Bảng 1. Trình tự nucleotide và chu kỳ nhiệt của 3 cặp mồi khuếch đại vùng trình tự rpoC1, matK và ITS

\begin{tabular}{|c|c|c|c|}
\hline Tên mồi & Trình tự (5'-3') & Chu kỳ nhiệt & Nguồn \\
\hline$\overline{r p o C 1-F}$ & GGCAAAGAGGGAAGATTTCG & \multirow{5}{*}{$\begin{array}{l}95^{\circ} \mathrm{C}-2 \text { phút; } 95^{\circ} \mathrm{C}-30 \text { giây; } \\
52^{\circ} \mathrm{C}-30 \text { giây; } 72^{\circ} \mathrm{C}-1 \text { phút } \\
\left(30 \text { chu kỳ; } 72^{\circ} \mathrm{C}-5 \text { phút }\right. \\
95^{\circ} \mathrm{C}-2 \text { phút; } 95^{\circ} \mathrm{C}-30 \text { giây; } \\
52^{\circ} \mathrm{C}-30 \text { giây; } 72^{\circ} \mathrm{C}-1 \text { phút } \\
\left(30 \text { chu kỳ; } 72^{\circ} \mathrm{C}-5 \text { phút }\right. \\
95^{\circ} \mathrm{C}-2 \text { phút; } 95^{\circ} \mathrm{C}-30 \text { giây; } \\
52^{\circ} \mathrm{C}-30 \text { giây; } 72^{\circ} \mathrm{C}-1 \text { phút } \\
\left(30 \text { chu kỳ; } 72^{\circ} \mathrm{C}-5 \text { phút }\right.\end{array}$} & \\
\hline rpoC1-R & CCATAAGCATATCTTGAGTTGG & & Kew (2007) \\
\hline matK-390F & CGATCTATTCATTCAATATTTC & & \\
\hline matK-1326R & TCTAGCACACGAAAGTCGAAGT & & (1990) \\
\hline ITS1 & TCCGTAGGTGAACCTGCGG & & $\begin{array}{l}\text { Kyndt et al. } \\
(2005)\end{array}$ \\
\hline
\end{tabular}

\subsection{Chỉ thị phân tử ISSR}

Bảy mồi ISSR được sử dụng để khảo sát sự đa hình của các trình tự lặp trong bộ gene sầu riêng.
Mỗi phản ứng với thể tích $25 \mu \mathrm{L}$ gồm $12 \mu \mathrm{L} \mathrm{BiH}_{2} \mathrm{O}$, $10 \mu \mathrm{L}$ master mix, $1 \mu \mathrm{L}$ mồi và $2 \mu \mathrm{L}$ DNA khuôn. Trình tự các đoạn mồi và chu kỳ nhiệt được mô tả ở Bảng 2. Sản phẩm PCR được di trên gel agarose $3 \%$.

Bảng 2. Trình tự mồi ISSR và chu kỳ nhiệt sử dụng trong nghiên cứu

\begin{tabular}{lll}
\hline Tên mồi & Trình tự & Chu kỳ nhiệt \\
\hline ISSR 03 & 5' -GAGAGAGAGAGAGAGAT- 3' & \\
ISSR 13 & 5'-AGAGAGAGAGAGAGAGCA-3' & \\
ISSR 22 & 5' -TGTGTGTGTGTGTGTGCC- 3' & $94^{\circ} \mathrm{C}-4$ phút; $94^{\circ} \mathrm{C}-1$ phút; $50^{\circ} \mathrm{C}-45$ \\
ISSR 31 & 5' -AGAGAGAGAGAGAGT- 3' & giây; $72^{\circ} \mathrm{C}-2$ phút $\left(35\right.$ chu kỳ); $72^{\circ} \mathrm{C}-$ \\
ISSR K1 & 5' -GAGAGAGAGAGAGAGACTC- 3' & 7 phút \\
ISSR K2 & 5' -GTGGTGGTGGTGAC-3' & \\
ISSR K3 & 5' -GAAGAAGAAGAAGAAGAA- 3' & \\
\hline
\end{tabular}

\subsection{Phân tích dữ liệu}

Các trình tự DNA được kiểm tra bằng chương trình Bioedit. Sau đó, các trình tự này được so sánh sự tương đồng với dữ liệu đã được công bố trên GenBank bằng công cụ BLAST (Basic Local Alignment Search Tool). Các trình tự được xác định độ chính xác bằng cách so sánh độ tương đồng trên cơ sở dữ liệu NCBI. Độ tương đồng càng cao, độ chính xác càng có ý nghĩa, được xác định qua các thông số sau: Organism (tên sinh vật), Querycover (mức độ trùng khớp của trình tự), E-value (độ tin cậy), Identity (mức độ tương đồng di truyền). Các trình tự $\mathrm{DNA}$ được dàn hàng (alignment) và xác định các SNPs bằng chương trình Bioedit.

Sản phẩm khuếch đại của các dấu phân tử ISSR của các giống sầu riêng được phân tích đa dạng di truyền bằng phần mềm NTSYSpc2.1 (Numberical
Taxonomy System Personal Computer) (Sneath and Sokal, 1973). Các dãy băng gel thu được từ sản phẩm PCR mồi ISSR và được nhập vào phần mềm Excel. Sự hiện diện hoặc không hiện diện của một băng nào đó trên gel được ghi nhận tuần tự là 1 và 0 . Sau đó xây dựng cây phát sinh chủng loại theo phương pháp UPGMA (Unweighted Pair Group Method using arithmetic Averages) để phân tích mối quan hệ di truyền.

\section{KẾT QUẢ VÀ THẢO LUẬN}

\subsection{Trình tự ITS}

Kết quả PCR các mẫu với mồi ITS được kiểm tra bằng phương pháp điện di trên gel agarose $2 \%$ (Hình 1) cho thấy các băng DNA xuất hiện rõ nét và không có băng phụ. So sánh với kích thước băng trên thang chuẩn $3 \mathrm{~kb}$ cho thấy đoạn gen ITS có kích thước khoảng $800 \mathrm{bp}$. 


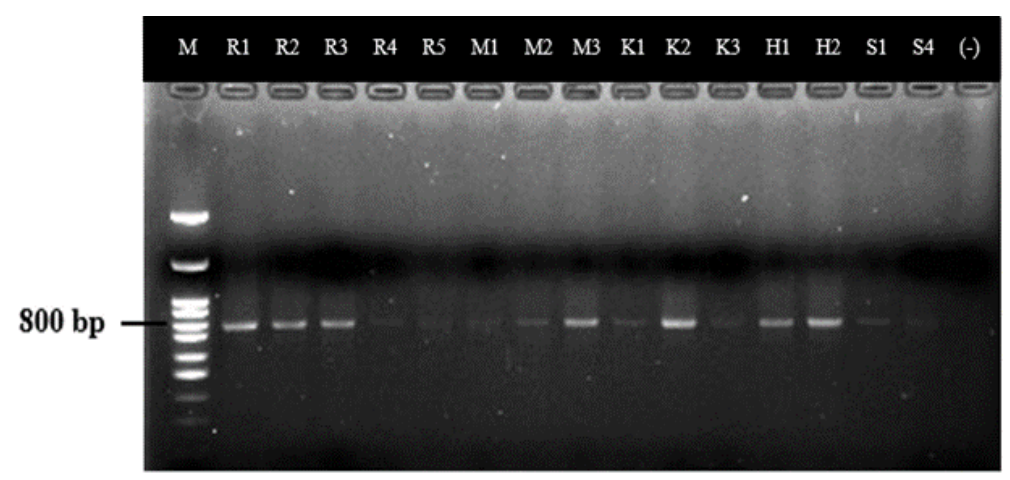

Hình 1. Phổ điện di với đoạn mồi ITS của 15 giống sầu riêng trên gel agarose $\mathbf{2 \%}$

M. Thang chuẩn 3 kb, R1. Ri 6 (Vĩnh Long), R2. Ri 6 (Tiền Giang), R3. Ri 6 (Bến Tre), R4. Ri 6 (Cần Tho*), R5. Ri 6 (Viện Cây ăn quả miền Nam), M1. Monthong (Vĩnh Long), M2. Monthong (Tiền Giang), M3. Monthong (Cần Tho), K1. Khổ qua xanh (Vĩnh Long), K2. Khổ qua xanh (Bến Tre), K3. Khổ qua xanh (Cần Tho), H1. Chín Hóa (Bến Tre). H2. Chín Hóa (Cần Tho), S1. Sũa hạt lép (Bến Tre), S4. Sũa hạt lép (Cần Tho) (-). Đối chúng âm.

Kết quả so sánh đã xác định được sự khác biệt ở giữa các trình tự gộp (consensus) và các giống thể hiện qua Bảng 3. Qua so sánh các trình tự, tìm được 6 SNPs giữa các trình tự và được kiểm tra peak lại trên chromatogram như sau: trong trình tự của các giống Ri 6, xuất hiện điểm sai khác tại vị trí 583 của trình tự sầu riêng Ri 6_Bến Tre, sau khi kiểm tra tín hiệu peak vị trí 603 nhận thấy tín hiệu chưa tốt ở vị trí này. Nucleotide $\mathrm{A}$ có tín hiệu peak cao hơn các tín hiệu của các nucleotidecòn lại và nhiễu nhiều. Ở vị trí này của trình tự sầu riêng Chuồng bò_Tiền Giang cũng xuất hiện nucleotide $\mathrm{A}$, sau khi kiểm tra peak vị trí 606 nhận thấy tín hiệu không phân biệt rõ giữa nucleotide $\mathrm{A}$ và $\mathrm{G}$.
Trong trình tự của các giống Monthong, trình tự Mongthong_Tiền Giang xuất hiện nucleotide G tại vị trí 717, các trình tự còn lại là nucleotide $\mathrm{C}$ sau khi kiểm tra peak ở trình tự này tại vị trí 734 cho thấy có sự chồng đỉnh giữa nucleotide $\mathrm{G}$ và $\mathrm{C}$, nhưng peak của nucleotide $\mathrm{G}$ cao hơn, có thể do bị nhiễm hoặc đột biến dị hợp vị trí này. Vị trí thứ 8 xuất hiện nucleotide $\mathrm{G}$ trên trình tự của giống sầu riêng Sáu Hữu Tiền Giang, các trình tự còn lại là nucleotide C, sau khi kiểm tra lại peak trên chromatogram tại vị trí 21 cho thấy nucleotide $\mathrm{G}$ bị chèn thêm, nên khả năng tại vị trí này do đột biến mất điểm.

Bảng 3. Vị trí SNPs trong trình tự nucleotide dựa trên vùng ITS của các giống sầu riêng

\begin{tabular}{|c|c|c|c|c|c|c|}
\hline \multirow{2}{*}{ Mẫu } & \multicolumn{6}{|c|}{ Vị trí nucleotide } \\
\hline & 8 & 444 & 583 & 614 & 717 & 718 \\
\hline Ri 6_Consensus & $\mathrm{C}$ & $G$ & $\mathrm{G}$ & $\mathrm{G}$ & $\mathrm{C}$ & $\mathrm{A}$ \\
\hline Ri 6_VCAQMN & . & . & . & . & . & . \\
\hline Ri 6_Tiền Giang & . & . & . & . & . & . \\
\hline Ri 6_Cần Thơ & . & . & 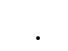 & . & . & . \\
\hline Ri 6_Bến Tre & . & . & A & . & & \\
\hline Monthong_Consensus & . & . & . & . & . & . \\
\hline Monthong_Vĩnh Long & . & . & . & . & . & . \\
\hline Monthong_Tiền Giang & . & . & . & . & $\mathrm{G}$ & . \\
\hline Monthong_Cần Thơ & . & . & . & . & . & . \\
\hline Chín Hóa_Consensus & . & . & . & . & . & . \\
\hline Chín Hóa_Bến Tre & . & . & . & . & . & . \\
\hline Chín Hóa_Cần Thơ & . & . & . & . & . & . \\
\hline Khổ qua xanh Vĩnh Long & . & & & & . & \\
\hline Chuồng bò_Tiề̀n Giang & . & $\mathrm{C}$ & A & A & & \\
\hline Sữa hạt lép_Cần Thơ & . & . & . & . & . & $\mathrm{G}$ \\
\hline Bí_Bến Tre & . & . & . & . & . & . \\
\hline Sáu Hữu Tiền Giang & & & & 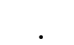 & 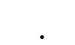 & \\
\hline
\end{tabular}

Ghi chú: C: nucleotide Cytosine; A: nucleotide Adenine; G: nucleotide Guanine; T: nucleotide Thymine 
Qua kết quả phân tích và so sánh 14 trình tự dựa trên vùng ITS, trình tự có độ dài dao động từ 600 700 bp sau khi được hiệu chỉnh. Phát hiện 6 SNPs giữa các trình tự trong cùng một giống (Ri 6 và Monthong) và các trình tự ở các giống có một mẫu (Chuồng bò Tiền Giang, Sữa hạt lép_Cần Thơ và Sáu Hữu_Tiền Giang). Trong đó, các vị trí này không đặc trưng cho giống sầu riêng Ri 6 nên chưa thể nhận diện được giống sầu riêng Ri 6 với các giống sầu riêng được sử dụng trong nghiên cứu. Tuy nhiên, từ các SNPs có sự khác biệt từ các cá thể sầu riêng Chuồng Bò_Tiền Giang, Sữa Hạt Lép_Cần Thơ và Sáu Hữu_Tiền Giang. Khi so sánh trình tự vùng ITS giữa các cá thể được sử dụng trong nghiên cứu thể hiện được sự đa dạng đối với các trình tự trong cùng giống và giữa các giống khác nhau.

\subsection{Trình tự matK}

Kết quả điện di sản phẩm PCR với mồi khuếch đại một phần trình tự matK được kiểm tra trên gel agarose $2 \%$ với thang chuẩn $1 \mathrm{~kb}$ (Hình 2 ) cho thấy các băng DNA được khuếch đại cho kết quả rõ nét, kích thước đồng đều giữa các mẫu, không xuất hiện băng phụ chứng tỏ mồi được thiết kế có tính đặc hiệu để DNA bắt được và nhân bản với các trình tự của sầu riêng. So sánh với kích thước băng trên thang chuẩn $1 \mathrm{~kb}$ cho thấy sản phẩm có kích thước khoảng $900 \mathrm{bp}$.

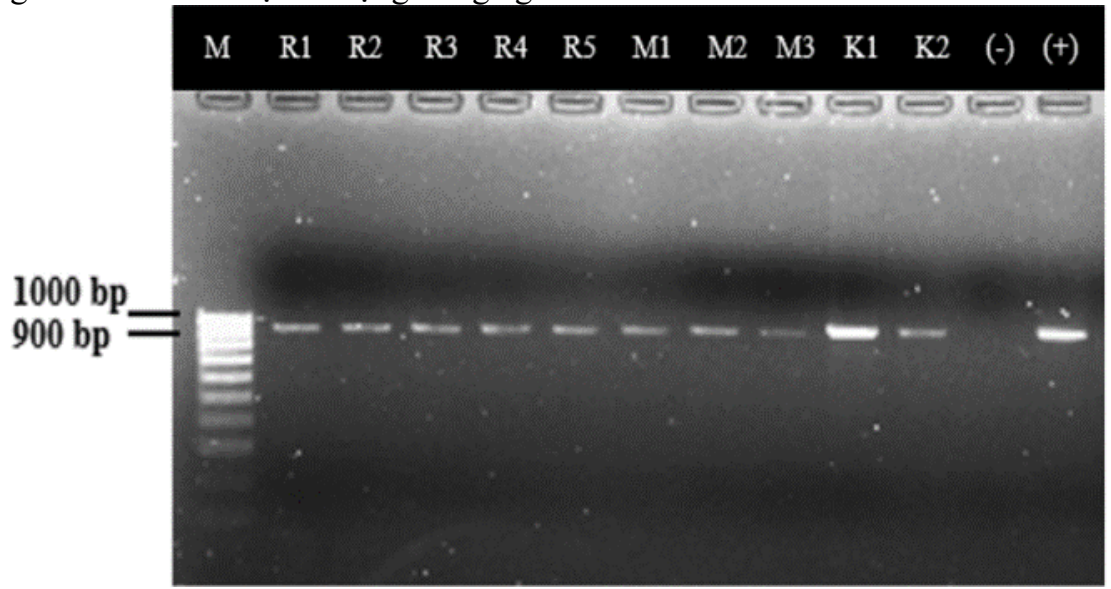

Hình 2. Phổ điện di với đoạn mồi vùng trình tự matK của 10 giống sầu riêng trên gel agarose $2 \%$

M. Thang chuẩn 1 kb, M. Thang chuẩn 3 kb, R1. Ri 6 (Vĩnh Long), R2. Ri 6 (Tiền Giang), R3. Ri 6 (Bến Tre), R4. Ri 6 (Cần Tho), R5. Ri 6 (Viện Cây ăn quả miền Nam), M1. Monthong (Vĩnh Long), M2. Monthong (Tiền Giang), M3. Monthong (Cần Tho), K1. Khổ qua xanh (Vĩnh Long), K2. Khổ qua xanh (Bển Tre), (-). Đối chứng âm, (+). Đối chứng duong

Trình tự của 17 mẫu được kiểm tra và hiệu chỉnh trên phần mềm BioEdit bằng cách đối chiếu các peak trên Chromatogram. Sau khi dàn hàng các trình tự trong cùng một giống bằng phần mềm BioEdit thì thu được trình tự chung của các giống sầu riêng Ri 6 (Ri 6_Consensus), Monthong (Monthong Consensus), Khổ qua xanh (Khổ qua xanh_Consensus), Chín Hóa (Chín Hóa_Consensus), Sữa hạt lép (Sữa hạt lép_Consensus), Chuồng bò (Chuồng bò Consensus).

Các trình tự Consensus của vùng trình tự matK được so sánh bằng công cụ BLAST trên NCBI để kiểm tra sự tương đồng với cơ sở dữ liệu của Ngân hàng gene và kết quả thu được có độ tương đồng từ 99,75-99,88\% với loài Durio zibethinus, độ bao phủ của trình tự Ri 6 Consensus so với các trình tự này dao động trong khoảng 91-100\%.
Kết quả các vị trí sai khác trong trình tự vùng trình tự matK được thể hiện qua Bảng 6 . Kết quả cho thấy có 9 SNPs và được kiểm tra peak trên chromatogram: trong các trình tự của giống Ri 6 , có 6 vị trí khác biệt ở giống này. Vị trí 662 của trình tự Ri 6 Viện Cây ăn quả miền Nam, sau khi kiểm tra peak cho thấy nucleotide $\mathrm{G}$ có tín hiệu thấp. Vị trí 739 và 740 của trình tự Ri 6_Cần Thơ, sau khi xem tín hiệu peak ở vị trí $760, \overline{761}$ trên chromatogram cho thấy chỉ xuất hiện đỉnh cho một nucleotideA nên hai vị trí này có thể do đột biến. Vị trí 759 cũng ở trình tự Ri 6_Cần Thơ là nucleotide $\mathrm{G}$ các trình tự khác là nucleotide $\mathrm{T}$, sau khi kiểm tra cho thấy tín hiệu nucleotide $\mathrm{G}$ chưa tốt và bị nhiễu. Vị trí 780 xuất hiện nucleotide $\mathrm{C}$ trên trình tự Ri 6 Cần Thơ các trình tự còn lại là nucleotide $\mathrm{G}$, kiểm tra peak cho thấy tín hiệu nucleotide $\mathrm{C}$ thấp nhưng không có tín hiệu nhiễu bên dưới. Trong trình tự các giống Chín Hóa, hai điểm không xuất hiện nucleotide là 
750 và 763 , sau khi kiểm tra peak (đoạn trình tự 765 - 805) tín hiệu khá tốt các peak có đỉnh cao và phân biệt được các nucleotide, nên đây có thể là hai vị trí đột biến cho thấy được khác biệt của giống Chín Hóa với các giống còn lại. Trình tự các giống Sữa hạt lép cho thấy có 2 vị trí khác biệt. Vị trí 798 xuất hiện sai khác giữa nucleotide $G$ và $T$, nên trình tự Consensus_SHL nên được thay thế bằng ký tự $\mathrm{K}$. Trình tự Sáu Hữu_Tiền Giang xuất hiện sai khác tại vị trí 793 là nucleotide $G$ các trình tự còn lại là nucleotide $\mathrm{C}$, kiểm tra cho thấy tín hiệu nucleotide $\mathrm{G}$ thấp nhưng có tín hiệu của nucleotide $\mathrm{A}$ bên dưới mà không phải là nucleotide $\mathrm{C}$. So sánh và kiểm tra đối chứng giữa 17 trình tự vùng trình tự matK có độ dài khoảng 800 bp đã tìm được một số vị trí sai khác giữa các trình tự trong cùng giống Ri 6 , giống Sữa hạt lép Bến Tre và cá hai thể của giống Chín Hóa_Bển Tre và giống Sáu Hữu_Tiền Giang. Trong các điểm sai khác chưa tìm được vị trí đặc trưng cho giống sầu riêng Ri 6 nên vẫn chưa thể nhận diện được giống sầu riêng Ri 6 với các giống sầu riêng được sử dụng trong nghiên cứu. Tuy nhiên, có thể nhận diện được hai cá thể Chín Hóa Bến Tre và Sáu Hữu_Tiền Giang. Kết quả phân tích cho thấy sự đa dạng trong trình tự vùng trình tự mat $\mathrm{K}$ giữa các cá thể sầu riêng với nhau.

Bảng 6. Vị trí SNPs trong trình tự nucleotide dựa trên trình tự matK của các giống sầu riêng

\begin{tabular}{|c|c|c|c|c|c|c|c|c|c|}
\hline \multirow{2}{*}{ Mẫu } & \multicolumn{9}{|c|}{ Vị trí nucleotide } \\
\hline & 662 & 739 & 740 & 750 & 759 & 763 & 780 & 793 & 798 \\
\hline Ri 6_Consensus & $\mathrm{C}$ & $\mathrm{T}$ & $\mathrm{G}$ & $\mathrm{C}$ & $\mathrm{T}$ & $\mathrm{A}$ & $\bar{G}$ & $\bar{A}$ & $\mathrm{~T}$ \\
\hline Ri 6_Vĩnh Long & . & . & . & . & . & . & . & . & . \\
\hline Ri 6_Bến Tre & . & . & . & . & . & . & . & . & . \\
\hline Ri 6_Cần Thơ & . & A & _ & . & G & . & $\mathrm{C}$ & & \\
\hline Ri 6_VCAQMN & G & & & & & & & & \\
\hline Monthong_Consensus & . & . & . & . & . & . & . & ${ }^{\circ}$ & . \\
\hline Monthong_Tiền Giang & . & . & . & . & . & . & . & 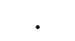 & . \\
\hline Monthong_Cần Thơ & . & . & . & . & . & . & . & . & . \\
\hline Khồ qua xanh_Consensus & . & . & . & . & . & . & . & . & . \\
\hline Khồ qua xanh_Vĩnh Long & . & . & . & . & . & . & . & . & . \\
\hline Khổ qua xanh_Bến Tre & . & . & . & . & . & . & . & . & . \\
\hline Khố qua xanh_Cần Thơ & . & . & . & . & . & . & . & $\cdot$ & . \\
\hline Chín Hữu_Consensus & . & . & . & - & . & . & . & & \\
\hline Chín Hữu_Bến Tre & . & . & . & - & . & - & . & & \\
\hline Chín Hữu_Cần Thơ & & & & & & & & & \\
\hline Sữa hạt lép_Consensus & . & . & . & . & . & . & . & . & $\mathrm{K}$ \\
\hline Sữa hạt lép_Bến Tre & . & . & . & . & . & . & . & 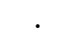 & $\mathrm{G}$ \\
\hline Sữa hạt lép_Cần Thơ & . & . & . & . & . & . & . & . & . \\
\hline Chuồng bò_Consensus & . & . & . & . & . & . & . & . & . \\
\hline Chuồng bò_Tiền Giang & . & . & . & . & . & . & . & 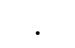 & . \\
\hline Chuồng bò_Bến Tre & . & . & . & . & . & . & . & . & . \\
\hline Bí_Bến Tre & . & . & . & . & . & . & . & 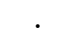 & . \\
\hline Sáu Hữu_Tiền Giang & . & & 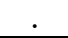 & . & . & . & . & $\mathrm{G}$ & . \\
\hline
\end{tabular}

Ghi chú: C: nucleotide Cytosine; A: nucleotide Adenine; G: nucleotide Guanine; T: nucleotide Thymine

\subsection{Trình tự rpoC1}

Kết quả PCR các mẫu với mồi khuếch đại vùng trình tự $r p o \mathrm{C} 1$ được kiểm tra bằng kỹ thuật điện di trên gel agarose $2 \%$ (Hình 3 ) cho thấy các băng DNA xuất hiện rõ nét, không có băng phụ chứng tỏ mồi được dùng để khuếch đại đặc hiệu. Mẫu đối chứng dương cho băng rõ nét, có kích thước bằng với các băng được khuếch đại, đối chứng âm không có băng xuất hiện chứng tỏ mẫu không bị ngoại nhiễm. So sánh với kích thước băng trên thang chuẩn cho thấy đoạn trình tự khuếch đại được có kích thước khoảng $500 \mathrm{bp}$. 


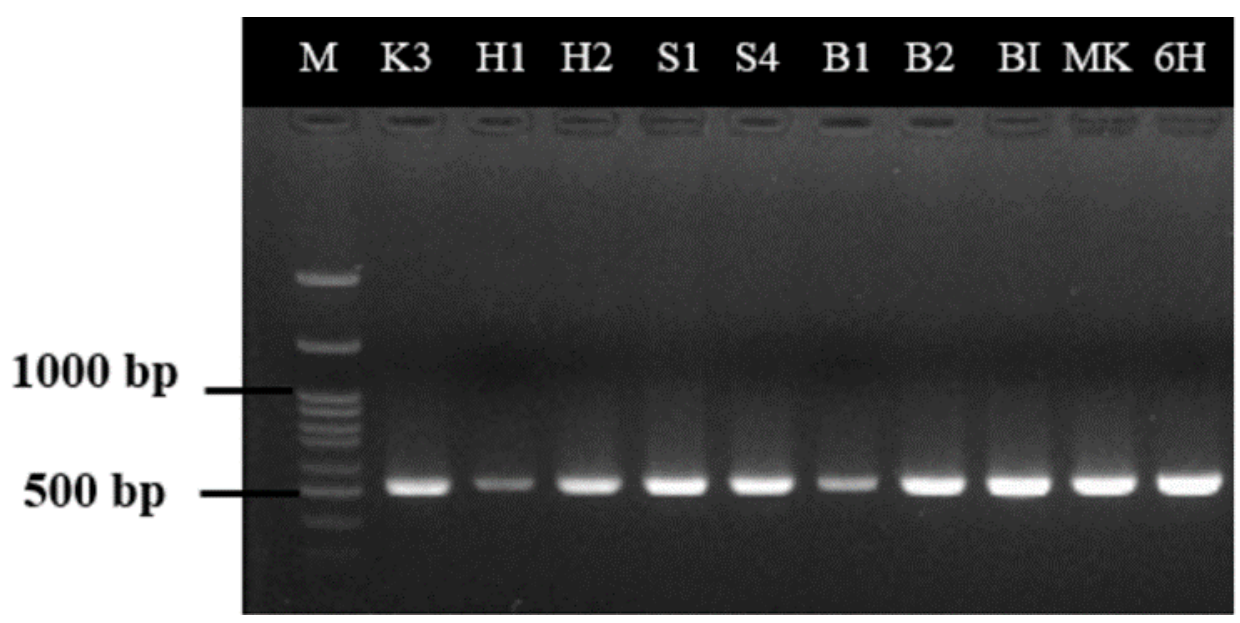

Hình 3. Kết quả khuếch đại vùng gen rpoC1 trên gel agarose $2 \%$

M. Thang chuẩn 3 kb, K3. Khổ qua xanh (Cần Tho), H1. Chín Hóa (Bến Tre). H2. Chín Hóa (Cần Tho'), S1. Sũa hạt lép (Bến Tre), S4. Sữa hạt lép (Cần Tho) B1. Chuồng bò (Tiền Giang), B2. Chuồng bò (Bến Tre), BI. Bí (Bến Tre), MK. Musang King (Vĩnh Long), 6H. Sáu Hũu (Tiền Giang).

Trình tự $r p o \mathrm{C} 1$ của 20 mẫu sầu riêng có kích thước 455 bp sau khi được kiểm tra và hiệu chỉnh trên phần mềm BioEdit bằng cách loại bỏ đoạn trình tự nhiễu ở hai đầu và kiểm tra peak trên chromatogram. Sau đó, các trình tự đã được dàn hàng và kết quả cho thấy không có biến đổi nucleotide trong trình tự đoạn gen $r p o \mathrm{C} 1$ và hoàn toàn giống nhau giữa các giống được sử dụng trong nghiên cứu này. Kết quả này cho thấy vùng gen $r p o \mathrm{C} 1$ có tính bảo tồn cao đối với các giống sầu riêng trong nghiên cứu này. Kết quả này cũng hoàn toàn phù hợp với nghiên cứu của Tassanee et al. (2018) trên 40 giống sầu riêng của Thái Lan, kết quả không thể phân biệt được các giống sầu riêng và trình tự nucleotide của gen $r p o \mathrm{C} 1$ có tính bảo toàn cao chưa phải là mã vạch tiềm năng để nhận dạng tốt các giống sầu riêng. Ngược lại, đối với nghiên cứu các loài Trám đen (Canarium nigrum) ở một số tỉnh phía Bắc nước ta, vùng trình tự rpo $\mathrm{C} 1$ lại cho kết quả nhận dạng tốt với các trình tự trong cùng chi Canarium (Đinh Thị Phòng và ctv., 2018). Như vậy, có thể nhận định rằng ở vùng trình tự $r p o \mathrm{C} 1$ có những đặc trưng riêng và hiệu quả phân biệt ở các loài khác nhau là không giống nhau.

Qua phân tích trình tự nucleotide của 3 trình tự $\mathrm{ITS}, m a t \mathrm{~K}$ và $r p o \mathrm{C} 1$, mối quan hệ di truyền gần gũi giữa các giống sầu riêng trong nghiên cứu thể hiện qua số SNPs đặc trưng cho từng giống còn khá khiêm tốn. Shearman et al. (2020) chỉ xác định được 9 SNPs khi phân tích trình tự bộ gene lục lạp hoàn chỉnh ở 24 cá thể sầu riêng thuộc giống Thái và Musang King.

\subsection{Chỉ thị phân tử ISSR}

ISSR trong phản ứng PCR trên DNA của bộ gen thu được từ các mẫu lá sầu riêng. Sản phẩm $\mathrm{PCR}$ được điện di trên gel agarose $2,5 \%$. Kết quả, sản phẩm của 2 mồi (ISSR31 và ISSRK1) không khuếch đại được trong tất cả các mẫu hoặc không hoàn toàn, hoặc do sản phẩm quá ít không thể ghi nhận được kết quả. Còn lại phổ diện điện di của 5 mồi (ISSR03, ISSR13, ISSR22, ISSRK1 và ISSRK2) được tiếp tục sử dụng để phân tích mối quan hệ di truyền của 20 mẫu sầu riêng.

Theo Bảng 4, có tổng số 57 phân đoạn được nhân lên với trung bình 11,4 băng/đoạn mồi. Trong đó, có 40 phân đoạn đa hình chiếm tỉ lệ $72 \%$. Số lượng băng đa hình dao động từ 6 (ISSR22) đến 20 (ISSR13) với trung bình đạt 8 , kích thước các băng dao động trong khoảng $200-2500$ bp. Trong số 5 chỉ thị của nghiên cứu này, ISSR13 cho nhiều phân đoạn nhất với 20 phân đoạn, trong đó có 11 phân đoạn đa hình chiếm $65 \%$, kế đến là ISSRK2 cho 15 phân đoạn với 11 phân đoạn đa hình chiếm 73,3\%. Còn lại ISSR22, ISSRK3 và ISSR03 cho số phân đoạn thấp hơn lần lượt là 6,7 và 9 . Kết quả này cao hơn trong một nghiên cứu tương tự trên sầu riêng của Vanijajiva (2012), với 5 chỉ thị ISSR đã khuếch đại được 50 phân đoạn, có kích thước từ 50-2.000 bp và có 19 phân đoạn đa hình chiếm $38 \%$. So sánh với quần thể 55 giống sầu riêng được nghiên cứu ở Indonesia của Angeliena et al. (2019), 11 đoạn mồi ISSR được sử dụng cho 83 allele đa hình $(93,25 \%)$. 
Bảng 4. Kết quả 5 mồi được phân tích sự đa dạng giữa 20 giống sầu riêng

\begin{tabular}{clrrr}
\hline TT & Primers & Tổng số băng & Băng đa hình & Tỉ lệ đa hình (\%) \\
\hline 1 & ISSR03 & 9 & 6 & 66,7 \\
2 & ISSR13 & 20 & 13 & 65,0 \\
3 & ISSR22 & 6 & 5 & 83,3 \\
4 & ISSRK2 & 15 & 11 & 73,3 \\
5 & ISSRK3 & 7 & 5 & 71,4 \\
& Tồng cộng & 57 & 40 & \\
& Trung bình & 11,4 & 8 & 72,0 \\
\hline
\end{tabular}

Sự khác biệt của 20 giống sầu riêng được ghi nhận dựa trên sự đa hình về kiểu gene được khuếch đại bởi 5 mồi ISSR có hệ số tương đồng dao động trong khoảng 0,61-0,97 (Hình 4). Qua kết quả phân nhóm trên, các mồi ISSR đã dùng trong nghiên cứu có thể nhận diện được hai cá thể của từng giống đơn lẻ như Musang King ở Vĩnh Long và Monthong ở Cần Thơ. Các mẫu của giống sầu riêng Ri 6 nằm ở 3 nhánh khác nhau, trong đó có 3 cá thể nằm cùng nhánh là Ri 6 (Vĩnh Long, Tiền Giang và Bến Tre) thuộc nhóm $\mathrm{I}$, còn 2 cá thể của giống này nằm ỏ nhóm II.A (Ri 6_Cần Thơ) và II.B (Ri 6_Viện CAQMN). Các mẫu của hai giống sầu riêng Sữa hạt lép (Bến Tre và Cần Thơ) và Chín Hóa (Bển Tre và Cần Thơ) không đi cùng một nhóm, qua đó ta có thể nhận định hai giống này không có cùng nguồn gốc. Hai mẫu sầu riêng Chuồng Bò (Tiền Giang và Bến Tre) và sầu riêng Bí (Bến Tre) nằm cùng nhánh III.B cho thấy rằng hai giống này có mối quan hệ họ hàng gần gũi. Đặc biệt qua phổ diện điện di có thể phân biệt được mẫu Musang King, giống này nằm riêng một nhánh trong cây phân loại và đây là giống sầu riêng nhập ngoại từ Malaysia. Điều này cũng phù hợp với kết quả nghiên cứu của Giang et al. (2016) trên các giống được thu từ Malaysia, Thái Lan và Việt Nam, trong đó giống D197 (Musang King) của Malaysia cũng nằm riêng một nhánh.

Kết quả phân tích dựa vào dấu phân tử ISSR đã phân chia 20 giống sầu riêng thu được ở bốn tỉnh của vùng ĐBSCL chia thành các 5 nhóm có hệ số tương đồng dao động khá xa trong khoảng 0,61 -
0,97 . Nguyên nhân do các mẫu thu tại các nhà vườn được trồng bằng các phương pháp khác nhau như ghép cành, trồng từ hột và nguồn gốc giống đến từ nhiều nơi khác nhau nên có sự đa dạng trong vật liệu di truyền trong quá trình sinh trường và phát triển. Cũng giống như một nghiên cứu về mối quan hệ di truyền của 14 giống sầu riêng ở Thái Lan có hệ số tương đồng dao động trong khoảng 0,632 - 1,00 (Vanijajiva, 2012). Một số nghiên cứu trên các giống cây ăn quả khác dựa vào dấu phân tử ISSR cũng cho kết quả tương tự. Nghiên cứu của Trần Nhân Dũng và Trần Thị Lệ Quyên (2012) trên các giống măng cụt cho thấy mức độ tương đồng của 32 dòng măng cụt trong nghiên cứu nằm trong khoảng $0,75-1,00$. Trong nghiên cứu trên 12 mẫu thanh trà, Lê Y Phụng và ctv. (2018) đã chỉ ra mức độ đa hình của quần thể có sự đa dạng cao và mức độ tương đồng dao động từ $0,58-0.86$. Hồ Viết Thế và ctv. (2019) phân tích đa dạng di truyền ở Chanh dây đã kết luận chỉ thị ISSR và RAPD tạo ra đều cho mức độ đa hình cao và kết quả phân tích cây phả hệ có sự biến động lớn trong thông tin di truyền giữa các mẫu phân tích và không tuân theo quy luật về vị trí thu mẫu. Khi nghiên cứu về mối liên hệ di truyền của các giống cây trồng trong canh tác nông nghiệp cho thấy con người là yếu tố quan trọng trong việc di chuyển giổng cây trồng giữa các vùng địa lý (Stankiewicz et al., 2001). Kết quả cho thấy có nhiều yếu tố tạo nên sự khác biệt trong quần thể như khả năng phát tán, ảnh hưởng của điều kiện ngoại cảnh đến quá trình sinh trưởng và phát triển (Kerdelhué et al., 2002). 


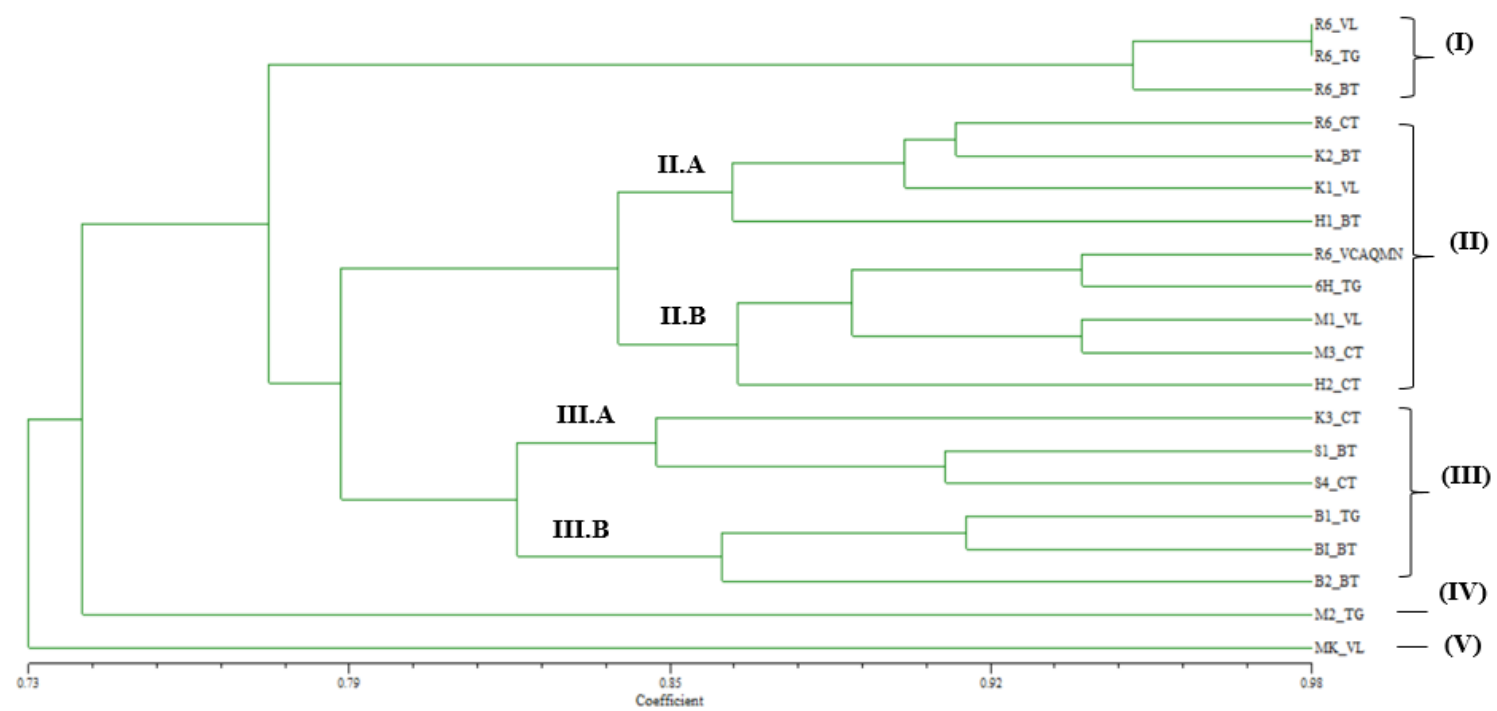

\section{Hình 4. Mối quan hệ di truyền của 20 mẫu giống sầu riệng dựa trên 5 đoạn mồi ISSR}

R1. Ri 6 (Vĩnh Long), R2. Ri 6 (Tiền Giang), R3. Ri 6 (Bến Tre), R4. Ri 6 (Cần Tho), R5. Ri-6 (Viện Cây ăn quả miền Nam), M1. Monthong (Vình Long), M2. Monthong (Tiền Giang), M3. Monthong (Cần Tho), K1. Khố qua xanh (Vĩnh Long), K2. Khổ qua xanh (Bến Tre), K3. Khổ qua xanh (Cần Tho), H1. Chín Hóa (Bến Tre). H2. Chín Hóa (Cần Tho'), S1. Sữa hạt lép (Bến Tre), S4. Sữa hạt lép (Cần Tho), S4. Sũa hạt lép (Cần Tho), B1. Chuồng bò (Tiền Giang), B2. Chuồng bò (Bến Tre), BI. Bí (Bến Tre), MK. Musang King (Vĩnh Long), 6H. Sáu Hũu (Tiền Giang).

\section{KẾT LUẬN}

Vùng trình tự ITS phát hiện 6 SNPs giữa các cá thể Ri 6_Bến Tre, Monthong_Tiền Giang, Chuồng bò Tiền Giang, Sữa hạt lép_Cần Thơ và Sáu Hữu_Tiền Giang. Đối với vùng trình tự matK tìm được 9 SNPs phân biệt được các cá thể Ri 6 (Cần Thơ và Viện Cây ăn quả miền Nam), Chín Hóa Bến Tre, Sữa hạt lép_Bến Tre và Sáu Hữu_Tiền Giang, nhưng chưa thể nhận diện được giống sầu riêng Ri 6 với các giống sầu riêng được sử dụng trong nghiên cứu. Nghiên cứu đã góp phần xây dựng bộ dữ liệu DNA mã vạch làm nền tảng định hướng cho các bước nghiên cứu tiếp theo trên sầu riêng ở ĐBSCL.

\section{TÀI LIỆU THAM KHẢO}

Angeliena, A., Ma'ruf, A., Sidiq, H. A., Anggraito, Y. U., Habibah, N. A., Huyop, F. Z., \& Retnoningsih, A. (2019, September). The diversity of superior Indonesian durians based on molecular markers. In AIP Conference Proceedings (Vol. 2155, No. 1, p. 020043). AIP Publishing LLC.

Bộ Công Thương. (2019). Báo cáo xuất nhập khẩu Việt Nam 2018. Nhà xuất bản Công Thương.

Bộ Nông nghiệp và Phát triển nông thôn. (2013). Quyết định về việc phê duyệt quy định vùng cây ăn quả chủ lực trồng tập trung và định hướng rải vụ một số cây ăn quả ở Nam bộ đến năm 2020 (1648/QĐ-BNN-TT).
https://www.mard.gov.vn/VanBan/Pages/hethong-van-ban.aspx.

Đinh Thị Phòng, Trần Thị Liễu, Vũ Thị Thu Hiền \& Hoàng Thanh Lộc. (2018). Đa dạng nucleotide vùng ITS gen nhân và các gen lục lạp (matK, rbcL, rpoC1) loài Trám đen (Canarium nigrum) ở một số tỉnh phía Bắc, Việt Nam. Tạp chí Công nghệ Sinh hoc, 16(3), 439-450.

Husin, N. A., Rahman, S., Karunakaran, R. \& Bhore, S. J. (2018). A review on the nutritional, medicinal, molecular and genome attributes of Durian (Durio zibethinus L.), the King of fruits in Malaysia. Bioinformation, 14(6), 265-270. 0.6026/97320630014265

Hebert, P. D., Cywinska, A., Ball, S. L., \& Dewaard, J. R. (2003). Biological identifications through DNA barcodes. Proceedings of the Royal Society of London. Series B: Biological Sciences. 270(1512), 313-321.

Hồ Viết Thế, Ngô Thị Kim Anh, Phan Thị Huyền Trang \& Tạ Thị Thanh Thúy. (2019, January 11). So sánh chỉ thị RAPD và ISSR trong phân tích đa dạng di truyền của một số giống chanh dây. Kỷ yếu Hội nghị Công nghệ Sinh học toàn quốc năm. Thành phố Hồ Chí Minh. https://dost.hochiminhcity.gov.vn/documents/10 14/Kyyeu2019.pdf

Kerdelhué, C., Roux, G., Forichon, J., Chambon, J., Robert, A., \& Lieutier, F. (2002). Population genetic structure of Tomicus piniperda $\mathrm{L}$. (Curculionidae: Scolytinae) on different pine 
species and validation of $T$. destruens (Woll.). Molecular Ecology, 11(3), 483-494.

Kyndt, T., Van-Droogenbroeck, B., RomeijnPeeters, E., Romero-Motochi, J. P., Scheldeman, X., Goetghebeur, P., \& Gheysen, G. (2005). Molecular phylogeny and evolution of Caricaceae based on rDNA internal transcribed spacers and chloroplast sequence data. Molecular Phylogenetics and Evolution, 37(2), 442-459.

Lê Y Phụng, Văn Quốc Giang, Nguyễn Lộc Hiền, Trần Văn Hâu \& Huỳnh Kỳ (2018). Khảo sát đặc điểm hình thái và đặc tính di truyền bằng dấu chỉ thị phân tử ISSR của các giống Thanh Trà (Bouea oppositifolia (Roxb.) Meisn) tại thị xã Bình Minh, tỉnh Vĩnh Long. Tạ chí Khoa hoc Truòng Đại học Cần Tho, 54(1B), 50-60.

Nguyễn Danh Vàn. (2008). Kĩ thuật canh tác cây ăn trái - Cây sầu riêng. Nhà xuất bản Tổng hợp Thành phố Hồ Chí Minh.

Rogers, S. O., \& Bendich, A. J. B. (1988). Extraction of DNA from plant tissues. Plant molecular Biology Manual. Kluwer Academic Publishers.

Shearman, J. R., Sonthirod, C., Naktang, C., Sangsrakru, D., Yoocha, T., Chatbanyong, R., \& Pootakham, W. (2020). Assembly of the durian chloroplast genome using long PacBio reads. Scientific reports, 10(1), 1-8.

Sneath, P. H., \& Sokal, R. R. (1973). Numerical taxonomy. The principles and practice of numerical classification. Systematic Zoology, 24(2), 263-268.
Stankiewicz, M., Gadamski, G., \& Gawronski, S. W. (2001). Genetic variation and phylogenetic relationships of triazine resistant and triazine susceptible biotypes of Solanum nigrum analysis using RAPD markers. Weed Research, 41(4), 287-300.

Tassanee, S., Theerachai, T., \& Narumol, T. (2018). Assessment of genetic relationship and identification of durian (Durio zibethinus Murr.) using nucleotide sequences of $\mathrm{rbcL}$ gene. Thai Journal of Science and Technology, 7(2), 191-201.

Trần Nhân Dũng \& Đỗ Tấn Khang. (2012). Đa dạng di truyền các giống xoài (Mangifera $\mathrm{sp}$.) bằng kĩ thuật sinh học phân tử. Tạp chí Khoa học Truòng Đại học Cần Tho, 22, 175-185.

Trần Nhân Dũng \& Trần Thị Lê Quyên. (2012). Đa dạng di truyền các giống/dòng Măng cụt (Garcinia mangostana L.) dựa trên dấu phân tử ISSR ở Bình Dương. Tạp chí Khoa hoc Truờng Đại học Cần Tho, 2(23a), 253-261.

Vanijajiva, O. (2012). The application of ISSR markers in genetic variance detection among Durian (Durio zibethinus Murr.) cultivars in the Nonthaburi province, Thailand. Procedia Engineering, 32(2012), 155-159. https://doi.org/10.1016/j.proeng.2012.01.1250

White, T. J., Bruns, T., Lee, S. J. W. T., \& Taylor, J. (1990). Amplification and direct sequencing of fungal ribosomal RNA genes for phylogenetics. PCR protocols: A guide to methods and applications. Academic Press. 